\title{
Strategic Planning Practices and Performance: The Story So Far in Parliamentary Service Commission in Kenya
}

\author{
Moses Mpisili Lemuna \\ Stephen Muathe \\ School of Business, Kenyatta University, Kenya
}

Doi:10.19044/esj.2021.v17n27p261

Submitted: 12 July 2021

Accepted: 12 August 2021

Published: 31 August 2021
Copyright 2021 Author(s)

Under Creative Commons BY-NC-ND

4.0 OPEN ACCESS

Cite As:

Lemuna M. M. \& Muathe S. (2021). Strategic Planning Practices and Performance: The Story So Far in Parliamentary Service Commission in Kenya. European Scientific Journal, ESJ, 17 (27), 261. https://doi.org/10.19044/esj.2021.v17n27p261

\section{Abstract}

The economic and political change in today's organizations is the norm and the social and technological change is highly accelerating posing extremely complex task and uncertainty to those responsible for strategic planning. Therefore, in executing various decisions there is need for managers to achieve a total understanding of strategic planning prior to effectively implementing it. This study investigated the influence of strategic planning practices on the performance of Parliamentary Service Commission in Kenya. The study specifically examined influence of environmental scanning, objective setting, stakeholder involvement and communication on performance of Kenyan Parliamentary Service Commission. The study was anchored on resource-based view; dynamic capability; balance score card and institutional theories. Descriptive survey research design was used. The target population comprised of eight hundred and five respondents who are the permanent staff of the Parliamentary Service Commission. However, a sample size of eighty-one respondents was selected using simple random sampling. Data was obtained using questionnaires and analyzed through descriptive and inferential statistics specifically multiple regressions and correlation. The study established that environmental scanning, objective setting, stakeholder involvement and communication had a positive and significant effect on the performance of Parliamentary Service Commission in Kenya. The study recommends that the Commission should identify the persons to be involved in the environmental scanning, create a competent team of employees and 
assign them relevant responsibilities. The Commission needs to set objectives that can be defined in a quantifiable and measurable terms within its strategic plan beside establishing responsibility for ensuring the task is undertaken and for writing it up for the report on stakeholder engagement. The Commission should link communication to the strategic plan, including the organization's mission, vision and values, its strategic goals and objectives.

Keywords: Strategic planning, Performance, Parliamentary service commission, Dynamic Capability Theory, Dynamic Capability Theory, Kenya

\section{Introduction}

Strategic planning gives an institution allowance in making fundamental choices or decisions by looking at what it is hoping to achieve and how it will do so. It is built by thoroughly analyzing the organization's present resources, collaborations, service mix or program, staff, governance, and structure (Alexander, 2015). Weick and Quinn (2016) observe that a strategic plan that is developed well acts as a master plan in making changes in an organization as it gives a description of weaknesses and strengths, vision, nature and sequence of the changes, required resources, and the people to guide changes if they are to be acquired from a source that is external or presently existing in the organization. Albanese and Van-Fleet (2013) observe that each organization has an external and internal environment interdepending. The continuous interaction and evolution of components of the internal environment and the dynamic and unstable external environment nature brought about by constant changes in social-cultural-demographic factors, political-legal aspects, technology, economy, and competition is making strategic management popular in understanding the strategic choices and position as they aim at performance excellence. Performance is supposed to be influenced positively by strategic planning since it helps select strategies enabling institutions in best allocation and exploitation of their strengths and resources corresponding to the external environment opportunities (Akinyi, 2017). Steiner (2014) posits that strategic planning is more a systems approach for managing an organization through its changing environment uncertainty in achieving set targets and not just a simple current budgets conclusions or functional plan combination. Owolabi (2015) perceives that if an organization is to survive, it should successfully operate with forces in an uncontrollable and unstable environment, which greatly affects decision-making. It then follows that strategy implementation commitment is correspondingly affected by strategic planning, thus enhanced organizational performance. Cheng, Kadir, and Bohari (2017) indicate that most SMEs in Malaysia have formal strategic planning. Moreover, in today's competitive market, SMEs are giving more attention to environmental scanning. Even with their benefit in the 
national economy, various problems are encountered by SMEs in Malaysia in their operations, affecting their business activities and sustainability. Cheng, Kadir, and Bohari (2017) further suggest a need for environment scanning to gather and analyze data from outside the company to assist in strategic planning efforts, help the managers better understand market development, and the management plan for future course of action. Umar, Muhammad, and Hassan (2020) perceive that strategic planning increases organization's longevity and performance in the Nigerian public sector, consequently arguing that public organizations should adopt a strategic planning process. It is important in determining the strategic planning's overall effectiveness for an institution. Umar, Muhammad, and Hassan (2020) further hypothesize that strategic planning ought to be planned flexibly in accommodating unexpected changes and other unforeseen factors that can negatively influence the effectiveness of strategic planning. According to Rajagopalan, Rasheed, and Datta (2019) strategic planning is utilized by key government decisionmakers, particularly due to drastic changes in the public sector, compelling them to think about the needs of the government strategically.

Wakahia (2017) observes that commercial banks in Kenya compete and their services and products differentiation is quite shallow thus requiring strategic planning of all the operations and advise that organizations that are successful must be able to manage cultural change and deliver a high customer service level. An essential strategic planning practice concept is to understand that for the success of an organization, everyone must work in ensuring the goals of the team are met. Consequently, strategy planning and implementation, evaluation of different options, resource capabilities and environmental trends analysis and objective setting are involved in strategic planning.

Organizational performance in various public sectors and entities is essential and pivotal in the dispensation of services to the citizens (Muathe, 2010). The Parliamentary Service Commission is no exception as it has to ensure delivery of exemplary services to both the National Assembly and the Senate as well as ensuring that the legislative agenda is undertaken to realize the set objectives and goals. However, challenges in the dispensation of services in the Parliamentary Service Commission have been hampered by inadequate technological advancement. According to Akinyele and Fasogbon (2016) application of strategies is the main method of attaining institutional goals and objectives with the aim of improving organizational performance. The difficulties emerge, however, from sources that are external and internal to the organization and will rely on the type of strategy, organization, and prevailing conditions. Organizations should then adopt proper strategic planning practices that create a productive alliance between organization's 
values and culture, environment's demands and nature; and the available resources to the company.

After Kenya gained its independence in 1963, Parliament of Kenya had the Westminster model, a hybrid system which had both presidential and parliamentary systems of government. In 1906 white settlers petitioned the Secretary of State for Colonies demanding representation in Kenya marking the start of the agitation for the current Parliament. This made the British government to issue an order to the in 1906 which established an Executive council chaired by the Governor, this paved way for setting up the Legislative Council (LEGCO) in 1955 which later evolved to become the legislative arm of government composed of elected and nominated members. Parliament as an arm of government started its quest to acquire autonomy and independence way back after independence. It wanted its own independence from the executive and to run its own calendar (Parliamentary Service Report 1998). This was aimed at reducing the influence and control of parliament by the executive. This led to the establishment of Parliamentary Service Commission (PARLSCOM) which was constitutionally created in 1999 by the Government of Kenya (GOK) comprising of the Secretary being the Clerk of National Assembly (CAN); seven Members of Parliament; Official Leader of the Opposition Party; Vice President and the Speaker of National Assembly (SNA) as the Chairperson. According to PARLSCOM (2000) Annual Report, in fulfilling this a two hundred staff member secretariat was created by the Commission, headed by the CAN deputized by two Senior Clerk Assistants responsible for parliamentary and public relations affairs respectively. PARLSCOM has since changed with the advent of the bicameral parliament and a transition from parliamentary to presidential system of government, with its membership comprising of the Speaker of the National Assembly as the Chairperson, five and three Members appointed from among the Members of the National Assembly and the Senate respectively, the Clerk of the Senate as the Commission Secretary and one man and woman who are non-sitting members of parliament appointed from among the members of the public. Since the enactment of the Parliamentary Service Act, 2000, the commission underwent various restructuring resulting in creation of four directorates each headed by a director, coupled with creation of specialized departments of independent parliamentary budget office, research affairs and legal services. Over time the secretariat has developed and grown to serve the ever-increasing demands of members of parliament which brought about acquisition of various buildings within parliaments precinct, with slightly over six hundred and fifty staff under nine directorates. The Parliamentary Service Act, 2000 was repealed in 2019 to align it to the Constitution of Kenya 2010, this has strengthened in law the office of the Parliamentary Joint Services (PJS) responsible for the provision of the shared services between the two Houses 
of Parliament and the Centre for Parliamentary Studies and Training (CPST) responsible for provision of learning and development programmes and building capacity for members of parliament and staff. The act has also facilitated formation of boards of management in every service within the Commission, which is now abbreviated as PSC, giving each service autonomy to run its own affairs. The Parliamentary Service Commission (PSC) as an institution is enshrined in Article 127 of the Constitution of Kenya 2010, with a core function of providing facilities and services ensuring bicameral parliament effective functioning. With the introduction of the senate as another house of parliament, strategic changes were inevitable for it to distinctively play its constitutionally outlined roles. This called for PSC to implement various changes in its human resource, infrastructure system and structure to accommodate different needs of the bicameral parliament, review the commissions systems and procedures to enable seamless working between the two Houses beside managing the expanded number of elected and nominated members of parliament. There was need for additional staff, more infrastructure to accommodate the expanded workforce, offices for members of both houses, which has increased from the previous membership of two hundred and twenty-two to the current three hundred and fifty in the National Assembly and sixty-eight Senators (PARLSCOM revised Strategic plan 20082018). Parliament had the responsibility to enact the forty-nine legislations necessary to operationalize the constitution through the support of PSC and to cater for the needs of the expanded legislature most of which have already been enacted.

The ultimate aim of strategic planning is increasing an organization's effectiveness and efficiency by providing a framework for management's vision and improving future and current operations (Nartisa, Putans \& Muravska, 2017). However, the economic and political are the norm and the social and technological change is highly accelerating posing extremely complex tasks and uncertainty to those responsible for strategic planning. Therefore, the need for managers to achieve a total understanding of strategic planning prior to effectively practicing in their various decisions. A study by Rintari and Moronge (2012) examined how Kenyan Public Institutions' performance is impacted by strategic planning practices and established a negative significant relationship between strategic planning practices studied on performance. A cross-sectional research design was used, utilizing a small sample size that may not represent the whole population. Mohammed, Gichunge and Were (2017) examined the relationship between Kenyan tourism sector firms' performance and strategic planning practices and found that resource identification influences performance. Njoroge (2018) examined how organizational performance is influenced by strategic planning and established that analysis of the external environment on what is done by the 
firms is needful. However, the study was a case of Nairobi CBD event planning firms. Subsequently, the current research sought to investigate how performance of the Parliamentary Service Commission in Kenya is influenced by strategic planning practices.

\section{Literature Review}

\subsection{Theoretical Review}

\subsubsection{Resource Based View Theory}

The study will be guided by the above theory by Grant in 1991, which advocates that a fixed unique asset essentially constitutes a firm and a company's control capacity to combine the assets giving permission for making the most market opportunities contributing to the company's performance. Further, through a set of abilities and resources, a firm might be regarded as allowing it to continue existing. Additionally, within the corporation system, resources are considered the most essential unit of analysis. A further regard may be given to an organization through a set of abilities and resources to continue existing. Resource-based View (RBV) theory points out four critical practices for organizations to gain competitive advantage as responding to external opportunities; converting internal weaknesses into strengths and developing and implementing strategy for exploiting internal strengths; embracing organizational culture that cannot be copied by competitors; creating specific human capital knowledge and skills; and deploying inelastic in supply valuable capabilities and resource bundles (Mata, Fuerst \& Barney, 1995; Afiouni, 2007). Founded on resource-based theory, all sources of competitive advantage should be exploited by organizations with the aim of developing unique strategies to yield customer value (O'Sullivan, 2011). Studies have revealed three assumptions of theory that the competitive advantage basis includes the skills for managing market and technical risks that perfectly immobile, if valuably and heterogeneously distributed across competing firms, capabilities and resources can be a sustainable competitive advantage source and capabilities and resources possessed by firms differ (Bordello, Ravarini, Wu \& Nigam, 2012). The RBV contends that depending on the resource's characteristics, a firm possesses a resources collection that may enhance the firm's capability, (Penrose, 2009). The theory is appropriate for the current study since strategic planning practices' efficient and effective implementation relies on resource capabilities of an organization in form of equipment, funds, materials and labour. To be a source of effective strategy planning process, a firm resource must be substitutable, imperfectly imitable, rare and valuable. 


\subsubsection{Dynamic Capability Theory}

It was propounded by Teece, Pisano and Shuen in the year 1997, with a view that dynamic capability is a firm's ability to integrate, build and reconfigure competences (external and internal) in addressing fast changing environments. The proponents of dynamic capability theory posit that competitive advantage of a firm is dependent on its ability to perform five primary functions namely integrate and coordinate resources and assets emerging from new resource base; embrace strategies of learning to ensure continuous development of skill for workers with additional skills to facilitate performance of duties effectively and efficiently; deploy resources into new ventures; develop mechanism to make competitors unable to copy the firm's processes and systems and reconfigure, transform and recombine assets and resources for new resource base formation (Zollo \&Winter, 2002). Dynamic Capability (DC) theory viewed the sources of firms' competitive advantage as its ability to reconfigure, build and integrate external and internal competences in addressing fast changing environments (Teece, Pisano \& Shuen, 1990, 1997). Dynamic capability is the ability of institutions to modify, extend and create their resource base structured in an organization to form part of its routines fixed in the institution with time (Helfat et al., 2007, Muithya \& Muathe, 2020). The theory basically assumes that light is shed on short-term competitive positions that can take part in longer competitive advantage building thus leading to an organization's long-run survival. According to Galvin, Rice and Liao (2014) in solving some of the RBV theory weaknesses, this theory was considered an alternative approach. Based on Teece, Pisano and Shuen (1997) DC theory provides processes that are path-dependent allowing organizations to cope with rapidly changing environments by reconfiguring, integrating and building their capabilities and resource portfolio. However, until the 1980s strategic management subjects had been of little interest. Barney (1991), appreciates a firm as a portfolio of human resources, intangible and tangible resources and capabilities. The capability of combining resources in a manner that is efficient and innovative. In this view, sustainable competitive advantage implies that when an organization implements a value that creates a strategy not simultaneously implemented by current or potential competitors and that the competitors do not have the ability to cope with this strategy's benefits. This theory is relevant to the study as competitive advantage has a relation to the firm's resource stock responsiveness to increasingly turbulent environments. Dynamic capabilities are needed by organizations in markets characterized by change and for keeping pace with competitive dynamics. 


\subsubsection{Balance Score Card Model}

The model was propounded by Kaplan and Norton (1996) as a framework for managing performance through which the daily operations are linked to strategy. It gives a holistic view of the enterprise based on the objectives of a business. Kaplan and Norton (1996) observe that the balance score card concept gives a strong means to translate the strategy and vision of a firm into a tool for effectively communicating strategic intent and motivating performance against the strategic goals established. It is a management system enabling strategy and vision clarification by an organization and translating them into actions. According to Malina and Selto (2015) balance score card connects performance measures by examining the strategic vision of a business from four points of view: internal business process, learning and innovation, customer and financial. Feltham and Xie (2017) recognize that within an industry, companies with a strategic plan and a defined core business to meet the objectives of their client tend to be leaders. The capability of measuring strategic objectives achievement and performance and ability of translating strategy of an organization into operational terms is the key to growth and success of an organization. According to Hoque and James (2016) the scorecard models use specifically, involves a traditional corporate management style reconsideration and stop relying entirely on financial measures for strategy development. There might be an argument that the scorecard tries a genuine marketing orientation by making sure of the existence of a co-operative organizational framework ensuring customer value. The relevance of this model is that organizations use balance score card in aligning their business activities with their strategy and vision. It measures the current future financial and operational measures of an organization. The success of any organization depends on its unique and dynamic interaction with the internal and external environment to formulate and adjust its strategy in order to achieve its goals. Accordingly, both non-financial and financial organizations' aspects have to be effectively and efficiently monitored and evaluated by the management.

\subsubsection{Institutionary Theory}

The Institutionary theory as propounded by Oliver (1991) places organizations at the core of the conduct and design of institutional analysis. Based on this perspective, organizations are wider institutions' representations perceived as taken-for-granted norms, rules and beliefs, shape the spreading and creation of practices, design features and forms of an organization. Oliver (1991) further avers that when institutionalized prescriptions are complied with, it is regarded as a way for increasing intelligibility, decreasing uncertainty and gaining legitimacy of activities and actions of an organization. Institution is described as standardized, conventional behavior patterns found 
across and within an organization that give meaning to social order and exchange. The behavior patterns include industry and organizational norms, routines and standards. The theory suggests that behaviors of an organization are copied and reproduced, this establishes norms taken for granted and in the end widespread standardized practice expectations. DiMaggio (2014) identifies that the institutional arguments rise in organizational analysis is a reflection of not being satisfied with theories putting efficiency at the center of actions of an organization. An organization does not operate in a vacuum; it must face many external influences like norms, conventions, legal requirements and cultural differences and deal with diverse actors' raised demands and choices explained in organizational practices and formal structures by the persisting expectations and resulting rules and beliefs. The theory tries to account for the reasons and processes for organizational behavior and the behavior patterns' effect within a broader, interorganizational context (DiMaggio \& Powell, 2016). The study of organizational institutions happens across research fields in communication, business and sociology and in the form of corporate legitimacy and reputation understanding by public relations practitioners. Similar forms and practices are possessed by the same industry's organizations, leading to a sector-specific homogenization. The theory sets a benchmark for this research as it shows that firms are not independent agents that seek to maximize economic opportunities, they are set within a social web of expectations and norms constraining and shaping managerial choice. The social logics or rules give overarching frameworks for interpretation of social situations and prescription of suitable collective behaviors and purposes. Strategies chosen by a manager are therefore not an unfettered act, it is a choice that social prescriptions constrain. Since similar conformity pressures and social expectations are experienced by similar organizations, similar managerial arrangements and strategies tend to be adopted.

\subsection{Empirical Review}

\subsubsection{Environmental Scanning}

Babatunde and Adebisi (2012), Njeru, Muathe and Muchemi (2013) examined how environmental scanning and organizational performance in a competitive business environment were related. Data collection was by structured questionnaire; analysis and interpretation by regression and correlation coefficient method. It was revealed by hypothesis one that organization performance and environmental scanning related significantly. A study by Vudzijena (2017) evaluated how performance of Harare based Small and Medium Retail Enterprises (SMEs) are impacted by environmental scanning. A quantitative study was conducted using the survey as the research strategy. Data collection was by questionnaire. A total of one hundred and fifty 
Retail SMEs were sampled using simple random sampling techniques. The research results showed that performance of retail SMEs in Harare and environmental scanning related positively and strongly. It was recommended that Retail SMEs in Harare should conduct environmental scanning as it leads to increased business performance. West and Olsen (2016) probed how firm performance was impacted by environmental scanning. They explored the industry of food service. Sixty-five food service firms' top management team members and chief executive officers were surveyed with the aim of ascertaining the degree to which the intended strategy of the firm is supported by environmental scanning. They utilized an industry structure model for environmental traits by Porter (1980) and interest and frequency scale by Hambrick (1979). The influence of scanning activity on performance was established as was the difference in low performing firms versus high scanning levels. They found differences that were so significant.

$H_{01}$ Environmental scanning influences performance of Kenyan Parliamentary Service Commission.

\subsubsection{Objective Setting}

Tang, Powell, Marino, Tang and Dickson (2015) measured how industrial munificence-goal attainment relationship was impacted by organizational goal setting. Data was obtained from a survey of two hundred and seventy-seven small and medium-size firms from Netherlands, Mexico, Sweden and Australia selected by stratified random sampling. They found that, to capitalize on industrial munificence, Chief Executive Officers (CEOs) needed to stretch the goal list as they keep an order of clear priority among the goals. Teo and Low (2016) did an Empirical study on how Singapore based high-tech Company's employee effectiveness on improving effectiveness of an organization was impacted by goal setting. From the findings the three tested hypotheses are evident, reliable and valid in their organization. Concurrence among the research interview participants was unanimous that in the relationship detailed in the conceptual model a role is played by goal setting and that employee effectiveness is impacted and effectiveness of an organization improved ultimately. Ikotun, Daniel and Adedapo (2016) considered how Nigerian Mobile Telecommunication Company's conflict management is impacted by organizational performance and objectives. It was revealed by some evidence from the analysis that conflict management and organizational performance on one hand and organizational objectives on the other hand had a positive statistically significant relationship. Therefore concluding that Nigerian mobile telecommunication company's effective conflict management is determined by organizational performance and objectives. 
$\mathrm{H}_{02}$ Objective setting influences performance of Kenyan Parliamentary Service Commission.

\subsubsection{Stakeholder Involvement}

Okoth (2016) reviewed how Mombasa tea warehousing companies' organizational performance, formulation and implementation of strategies is influenced by involvement of stakeholders; data collected indicated that involvement of stakeholders positively correlated with performance. This was even so when stakeholders were involved moderately in formulation and implementation strategies and that the performance index was higher relatively in organizations that highly involved the stakeholders than in those with low involvement. A study by Adewale and Esther (2012) inquired into how organizations performance and involvement of stakeholders in strategic planning related among the employees of the University of Venda. It was found out that the management cadre absolutely dominated the strategic planning process hence other stakeholders were sent into the doldrums. Practically from the findings, in the planning process, there is least involvement of those directly affected. Chepkoech and Waiganjo (2015) explored how Kenyan commercial banks' strategic change implementation is impacted by stakeholders. They inspected the National Bank of Kenya. A descriptive research design was used with one hundred and twenty management level staff working in Nairobi Central Business District (CBD). National Bank of Kenya (NBK) branches selected as respondents, the staff from different levels of management in the bank were selected. Questionnaire was employed in data collection. It was discovered that in the implementation of Kenyan commercial banks' strategic change, a positive and significant role is played by stakeholders.

$\mathrm{H}_{\mathrm{O} 3}$ Stakeholder involvement influences performance of Kenyan Parliamentary Service Commission.

\subsubsection{Communication}

Kibe (2014) studied how organizational performance is influenced by communication strategies in the case of the Kenya Ports Authority. An empirical evaluation of four strategies of communication which could impact organizational performance namely formal communication channels, organization structure, group effort and open-door policy was done. Two hundred respondents from the corporate development department in the corporate service division took part in the study. It was found out that, in highperformance, a central role is played by communication strategies. Ngozi and Ifeoma (2015) scrutinized how Nnamdi Azikiwe University's organizational performance is impacted by effective communication relying on both secondary and primary data. A total of one hundred and seventy non-academic 
and one hundred and thirty academic staff of the Nnamdi Azikiwe Universities formed the study's population. The findings revealed that in an organization's efficient and effective employee management performance effective communication is the solution. Otoo (2016) questioned how Ghana Revenue Authority's employee performance is influenced by communication. Primary data was used and a descriptive survey was adopted. Two hundred respondents were selected by simple random sampling. Regression, correlation and mean results were used in analyzing data. It was discovered that different performance indicators of employees correlate with different effective organizational communication measures.

Regression, correlation and mean results were used to analyze data. It was evident that different performance indicators of employees correlate with different effective organizational communication measures.

$\mathrm{H}_{04}$ Communication influences performance of Kenyan Parliamentary Service Commission.

\section{Research Methodology}

The study employed descriptive survey research design. Based on Muathe, (2010), Muathe, Wawire and Ofafa (2013) and Dulock (2014) the design is a scientific method that involves description and observation of a subject's behavior with no influence. The targeted population was eight hundred and five respondents comprising twenty Heads of Department and seven hundred and eighty-five employees from the Parliamentary Service Commission. The sample size was eighty-one respondents comprising staff at PARLSCOM Scale (Job Group Scale 6) and above. Data was obtained by use of questionnaires. Inferential statistics including multiple regressions and correlation analysis was used in determining the relationship among variables.

\section{Findings and Discussion}

\subsection{Correlation Analysis Results}

Correlation analysis was done to quantify the association between the independent and dependent variables as shown in Table1. 
Table 1: Correlation Analysis

\begin{tabular}{|c|c|c|c|c|c|c|}
\hline & & $\begin{array}{l}\text { Environmen } \\
\text { tal scanning }\end{array}$ & $\begin{array}{l}\text { Objective } \\
\text { setting }\end{array}$ & $\begin{array}{l}\text { Stakeholder } \\
\text { involvement }\end{array}$ & $\begin{array}{l}\text { Communica } \\
\text { tion }\end{array}$ & $\begin{array}{l}\text { Organizatio } \\
\text { nal } \\
\text { performance }\end{array}$ \\
\hline $\begin{array}{l}\text { Environmental } \\
\text { scanning }\end{array}$ & $\begin{array}{l}\text { Pearson } \\
\text { Correlation } \\
\text { Sig. (2-tailed) } \\
\mathrm{N}\end{array}$ & $\begin{array}{l}1 \\
74 \\
74\end{array}$ & & & & \\
\hline Objective setting & $\begin{array}{l}\text { Pearson } \\
\text { Correlation } \\
\text { Sig. (2-tailed) } \\
\text { N }\end{array}$ & $\begin{array}{l}.638 \\
.000 \\
74\end{array}$ & $\begin{array}{l}1 \\
74\end{array}$ & & & \\
\hline $\begin{array}{l}\text { Stakeholder } \\
\text { involvement }\end{array}$ & $\begin{array}{l}\text { Pearson } \\
\text { Correlation } \\
\text { Sig. (2-tailed) } \\
\text { N }\end{array}$ & $\begin{array}{l}.713 \\
.000 \\
74\end{array}$ & $\begin{array}{l}.687^{* * *} \\
.000 \\
74\end{array}$ & $\begin{array}{l}1 \\
74\end{array}$ & & \\
\hline Communication & $\begin{array}{l}\text { Pearson } \\
\text { Correlation } \\
\text { Sig. (2-tailed) } \\
\text { N }\end{array}$ & $\begin{array}{l}.563^{*} \\
.001 \\
74\end{array}$ & $\begin{array}{l}.668^{* * *} \\
.000 \\
74\end{array}$ & $\begin{array}{l}.247^{* *} \\
.007 \\
74\end{array}$ & & \\
\hline $\begin{array}{l}\text { Organizational } \\
\text { performance }\end{array}$ & $\begin{array}{l}\text { Pearson } \\
\text { Correlation } \\
\text { Sig. (2-tailed) } \\
\text { N }\end{array}$ & $\begin{array}{l}.803^{* *} \\
.000 \\
74\end{array}$ & $\begin{array}{l}.669^{* *} \\
.000 \\
74\end{array}$ & $\begin{array}{l}.696^{* * *} \\
.000 \\
74\end{array}$ & $\begin{array}{l}.786^{* *} \\
.000 \\
74\end{array}$ & $\begin{array}{l}1 \\
74\end{array}$ \\
\hline
\end{tabular}

The results show that environmental scanning had a strong relationship with the organizational performance with a Pearson's $r$ value of 0.803 . This finding agrees with Babatunde and Adebisi (2012) study that examined how strategic environmental scanning and organizational performance in a competitive business environment were related and revealed by hypothesis one that organization performance and strategic environmental scanning related significantly. The Pearson's $r$ for the correlation between objective setting and organizational performance variables is 0.669 and vice versa which is close to 1 with a significant value of 0.00 which is less than 0.05 . This shows a strong relationship meaning that objective setting is strongly correlated with organizational performance. This finding is consistent with the finding of an empirical study done by Teo and Low (2016) on how Singapore based hightech Company's employee effectiveness on improving effectiveness of an organization was impacted by goal setting which found that the relationship detailed in the conceptual model a role is played by goal setting and that employee effectiveness is impacted and effectiveness of an organization 
improved ultimately. Stakeholder involvement had a strong relationship with the organizational performance with a Pearson's $r$ value of 0.696 with a significance value of 0.00 . This finding agree with Okoth (2016) study that examined how Mombasa tea warehousing companies' organizational performance, formulation and implementation of strategies is influenced by involvement of stakeholders and established that the performance index was higher relatively in organizations that highly involved the stakeholders than in those with low involvement. Communication was also found to have influenced the performance of the organization to a greater extent with a Pearson's $r$ value of 0.786 with a significance value of 0.00 . This finding agrees with Ngozi and Ifeoma (2015) study that examined how Nnamdi Azikiwe University's organizational performance is impacted by effective communication and the findings showed that in an organization's efficient and effective employee management performance effective communication is the solution.

\subsection{Regression Analysis}

Regression analysis was done to estimate the relationship between dependent variables (organizational performance) and Independent variables (environmental scanning, objective setting, stakeholder involvement and communication). The results are presented in Table 2.

Table 2: Regression Analysis

\begin{tabular}{|l|l|l|l|l|}
\hline & & & & \\
Model & $\mathrm{R}$ & $\mathrm{R}$ Square & Adjusted R Square & $\begin{array}{l}\text { Std. Error of the } \\
\text { Estimate }\end{array}$ \\
\hline 1 & $.948^{\mathrm{a}}$ & .899 & .898 & .157 \\
\hline
\end{tabular}

From the results, the independent variables that were studied, explain a factor of $0.898(89.8 \%$ ) of performance of Kenyan Parliamentary Service Commission as represented by the adjusted $\mathrm{R}$ square. This therefore means that other factors not studied in this research contribute $10.2 \%$ of the organizational performance.

Table 3: Analysis of Variance

\begin{tabular}{|ll|l|l|l|l|l|}
\hline Model & & Sum of Squares & df & Mean Square & F & Sig. \\
\hline 1 & Regression & 67.173 & 4 & 16.793 & 679.705 & $.000^{\mathrm{a}}$ \\
& $\begin{array}{l}\text { Residual } \\
\text { Total }\end{array}$ & 7.560 & 70 & .025 & & \\
\hline
\end{tabular}


From the results, the study significance value was at $0.000^{\mathrm{a}}$ showing that the model was significant as it was less than 0.05 and thus the model predicts how independent variables studied influenced the organizational performance variable. The results also indicate that $\mathrm{F}$ calculated value is greater than the value of $F$ tabulated (679.705> 16.793) at 5\% significance level confirming the model was significant.

Table 4: Coefficients

\begin{tabular}{|c|c|c|c|c|c|c|}
\hline \multirow[b]{2}{*}{ Mod } & & \multicolumn{2}{|c|}{ Unstandardized Coefficients } & \multirow{2}{*}{$\begin{array}{l}\text { Standardized } \\
\text { Coefficients }\end{array}$} & \multirow[b]{2}{*}{$\mathrm{t}$} & \multirow[b]{2}{*}{ Sig. } \\
\hline & & B & Std. Error & & & \\
\hline \multirow[t]{5}{*}{1} & (Constant) & .610 & .942 & & 3.831 & .000 \\
\hline & Environmental scanning & .680 & 235 & 4.063 & 2.290 & .003 \\
\hline & Objective setting & .759 & .312 & 1.218 & 1.926 & .001 \\
\hline & Stakeholder involvement & .621 & .133 & 3.273 & 2.948 & .002 \\
\hline & Communication & .596 & .128 & 1.336 & 1.246 & .000 \\
\hline
\end{tabular}

From the findings, holding environmental scanning, objective setting, stakeholder involvement and communication to constant, performance of Kenyan Parliamentary Service Commission would be 0.610. In addition, objective setting was found to have a greater influence on organizational performance at $75.9 \%$ compared to other variables studied, followed by environmental scanning at $68.0 \%$, stakeholder involvement at $62.1 \%$ and lastly communication at $59.6 \%$. The established regression equation by the study was:

$$
\begin{array}{cl}
\mathrm{Y}=0.610+0.680 \mathrm{X}_{1}+0.759 \mathrm{X}_{2}+0.621 \mathrm{X}_{3}+0.596 \mathrm{X}_{4} \\
\text { Where } \quad \mathrm{Y}=\text { Organizational performance } \\
\mathrm{X}_{1}=\text { Environmental scanning } \\
\mathrm{X}_{2}=\text { Objective setting } \\
\mathrm{X}_{3}=\text { Stakeholder involvement } \\
\mathrm{X}_{4}=\text { Communication }
\end{array}
$$

The study examined that environmental scanning had a positive and significant relationship on the performance of Kenyan Parliamentary Service Commission as indicated by beta values $(\beta=4.063, \mathrm{P}<0.05)$. This finding is supported by the findings of a study by Vudzijena (2017) that evaluated how performance of Harare based Small and Medium Retail Enterprises are impacted by environmental scanning the study results showed that performance of retail SMEs in Harare and environmental scanning related positively and strongly. The study examined that objective setting had a positive and significant relationship on the performance of Kenyan 
Parliamentary Service Commission as indicated by beta values $(\beta=1.218$, $\mathrm{P}<0.05)$. This finding is contrary to Teo and Low (2016) study on how Singapore based high-tech Company's employee effectiveness on improving effectiveness of an organization was impacted by goal setting which found that the relationship detailed in the conceptual model a role is played by goal setting and that employee effectiveness is impacted and effectiveness of an organization improved ultimately. The study found that stakeholder involvement had a positive and significant relationship on the performance of Kenyan Parliamentary Service Commission as indicated by beta values $(\beta=3.273, \mathrm{P}<0.05)$. This finding is in line with Chepkoech and Waiganjo (2015) study that investigated how Kenyan commercial banks' strategic change implementation is impacted by stakeholders and discovered that in the implementation of Kenyan commercial banks' strategic change, a positive and significant role is played by stakeholders. The study determined that communication had a positive and significant relationship on the performance of Kenyan Parliamentary Service Commission as indicated by beta values as indicated by beta values $(\beta=1.336, \mathrm{P}<0.05)$. This is in line with Otoo (2016) study on how Ghana Revenue Authority's employee performance is influenced by communication and established that different performance indicators of employees correlate with different effective organizational communication measures.

\section{Conclusion and Policy Recommendation Conclusion}

The study concludes that environmental scanning helps the organization to understand what is happening both inside and outside the organization and to increase the probability that the organizational strategies developed will appropriately reflect on the organizational environment. Environmental scanning is necessary because there are rapid changes taking place in the environment that has a great impact on the working of the organization hence environmental analysis is an extremely important tool in understanding and decision- making in all situation of the organization. Success of the organization depends upon the precise decision-making ability therefore environmental analysis enables the firm to select the best option for the success and performance of the organization. The study also concludes that setting a goal establishes a clearly defined and thought-out direction which will lead an organization to eventually achieve its longer-term wellness goals. Having this clear direction allows the organization to focus on the smaller steps it will take to ultimately achieve its success; by establishing clear objectives, the organization gives its employees a greater sense of purpose and responsibility and motivates them to keep working and give their best. The study further concludes that stakeholder involvement brings people together 
to pool knowledge, experience and expertise to co-create solutions and helps to reduce the level of risk within an organization and improves governance; effective engagement of stakeholders helps translate stakeholder needs into organizational goals and creates the basis for effective strategy development. Key stakeholder opinions and insights are incredibly valuable in the early stages of the planning and development processes. Stakeholder involvement helps build collaborative partnerships and new relationships that generate value and helps build collaborative partnerships and new relationships that generate value. The study finally concludes that effective communication encourages the flow of new ideas that could help the organization operate more efficiently, as communication creates a sense of employee feeling that they carry their fair share of the workload, enhancing the work experience in a beneficial way. Better communication techniques assist in helping employees to comprehend their roles which in turn enhance their performance of their assigned duties better. Clear and open communication averts misunderstanding between manager and employee. Learning and adjusting to different communication styles also enhances positive organizational relationships.

\section{Policy Implications}

The study recommends that the Commission should identify the persons to be involved in the environmental scanning and create a competent team of employees and assign them relevant responsibilities. Involve the relevant stakeholders during the process of analysis of the environment that the commission operates in and let the employees work in partnership when focusing on direct impact on decision-making and strategic planning. Create an action plan to apply changes and measure the results while continually scanning the environment keeping an eye out for new trends that could occur. The study also recommends that the commission need to set objectives that can be defined in quantifiable and measurable terms within its strategic plan. The goal should be specific, measurable, attainable, relevant, and timely but also reflect on the outcome. Identify the behaviors that are critical for performance, establish potential rewards and discipline and continue developing abilities to enhance performance. The study further recommends that the commission should establish responsibility for ensuring the task is undertaken and for writing it up for the report on stakeholder engagement. Establish responsibility for ensuring the task and is undertaken for receiving representations and ensuring proper recording of responses. Establish who is responsible for receiving and collating the representations and recording outcomes and their justification so they can be made publicly available. The study finally recommends that the commission should link communication to the strategic plan, including the organization's mission, vision and values, its 
strategic goals and objectives and its employment brand. Safeguard credibility to establish loyalty and build trust and maintain consistency to establish a strong employment brand. Listen to employees and to members of the leadership team; provide feedback; and prepare managers in their roles as organizational leaders.

\section{Limitations}

Cognizance of the confidentiality concerns, respondents feared sharing some sensitive information. However, the study purpose was made known to them by presenting an introductory letter from the University. Owing to the population size, the study was limited to cover the whole population; to curb this, obtaining a representative sample size sampling was carried out. Some of the senior officers focused by the study were very busy posing a challenge to schedule a suitable timing hence leading to continuous meeting re-scheduling. The researcher ensured to keep to the management appointments.

\section{References:}

1. Adewale, A. R., \& Esther, M. M. (2012). The Relationship Between Stakeholders Involvement In Strategic Planning and Organizations Performance A Study Of The University Of Venda. International Business \& Economics Research Journal (IBER), 11(11), 1175-1190.

2. Akinyi, J. (2017). Challenges Facing Private Secondary Schools in Implementation of Strategic Plans in Kisumu West (Unpublished MBA Project).University of Nairobi, Nairobi, Kenya

3. Albanese, R. \& Vanfleet D.D. (2013).Organizational Behavior: A Managerial Viewpoint.Chicago: Dryden Press.

4. Alexander, L. D. (2015). Successfully implementing strategic decisions. Long Range Planning, 18(2), 91- 97.

5. Babatunde, B. O., \& Adebisi, A. O. (2012). Strategic Environmental Scanning and Organization Performance in a competitive business environment. Economic Insights-Trends \& Challenges, 64(1), 45 53

6. Balcazar, F., Hopkins, B. L., \& Suarez, Y. (2015). A critical, objective review of performance feedback. Journal of Organizational Behavior Management, 7(3-4), 65-89.

7. Cheng, W. H., Kadir, K. A., \& Bohari, A. M. (2017). The strategic planning of SMEs in Malaysia: a view of external environmental scanning. International Journal of Business and Society, 15(3), 437 448

8. Chepkoech, C. \& Waiganjo, E. W. (2015). Role of stakeholders in the implementation of strategic change in commercial banks in Kenya: A case study of National Bank of Kenya Limited. International 
Academic Journal of Human Resource and Business Administration, 1 (5), 55-82

9. DiMaggio, P. (2014). Interest and agency in institutional theory. In L. Zucker (Ed.), Institutional patterns and organizations: Culture and environment (pp. 3-22). Cambridge, MA: Ballinger.

10. DiMaggio, P. J., \& Powell, W. W. (2016). The iron cage revisited: Institutional isomorphism and collective rationality in organization fields. American Sociological Review, 48(2), 147-160.

11. Dulock, H. L. (2014). Research design: Descriptive research. Journal of Pediatric Oncology Nursing, 10(4), 154-157

12. Feltham, G. \& Xie, J. (2017). Performance measure congruity and diversity in multi-task principal/agent relations. The Accounting Review, 69, 429-453

13. Hoque, Z., \& James, W. (2016). Linking Balance Score Card measures to size and market factors: Impact on organizational performance. Journal of Business Management, 2(1), 1 - 17

14. Ikotun, S. I., Daniel, O. A., \& Adedapo, O. A. (2016). Impact of Organizational Objectives and Performance in Conflict Management in a Nigerian Mobile Telecommunication Company. European Journal of Business and Management, 8(3), 23 -35 .

15. Kaplan, N., \& Norton, P. (1996). The Balance Score Card; Translating Strategy into Action. Harvard business School press, Boston

16. Kibe, C. W. (2014). Effects of communication strategies on organizational performance: A case study of Kenya Ports Authority. European Journal of Business and Management, 6(11), 610.

17. Malina, M. A., \& Selto, F. H. (2015). Communicating and controlling strategy: an empirical study of the effectiveness of the Balance score Card. Journal of Management, 1(2), 47 - 58

18. Mohammed, A., Gichunge, E. \& Were, E. (2017). Relationship between strategic planning practices and performance of tour firms in the tourism sector in Kenya: A survey of selected tour firms in Nairobi, Kenya. International Academic Journal of Human Resource and Business Administration, 2(3), 521-534

19. Muathe, S.M., Wawire, N.W., \& Ofafa, G.A., (2013). An Empirical Study on the Relationship Between Organizational Factors and Adoption of ICT among Health Related SMEs in Nairobi, Kenya, International Journal of Arts and Commerce, Vol. 2 Issues 3. PP. 1-16

20. Muathe, S. M. A. (2010). The determinants of adoption of information and Communication technology by small and medium Enterprises 
within the health sector in Nairobi, Kenya. Unpublished $\mathrm{PhD}$ Thesis, Kenyatta University.

21. Mugenda, O. M. \& Mugenda, A. G. (2003). Research Methods: Quantitative and Qualitative approach, Nairobi: Act press

22. Muithya, V.M. \& Muathe (2020). Dynamic capabilities and performance in the context of microfinance institutions in Kenya: $A n$ exploratory study.

23. Nartisa, I, Putans, R. \& Muravska, T. (2017). Strategic planning and management in public and private sector organizations in Europe: comparative analysis and opportunities for improvement. European Integration Studies, 6(2), 140-149

24. Ngozi, N. P., \& Ifeoma, O. R. (2015). The Role of effective Communication on Organizational Performance: A Study of Nnamdi Azikiwe University, Awka. Review of public administration and management, 400(3617), 1-18.

25. Njeru, E. N., Muathe, S.M., \& Muchemi, A. W., (2013). Challenges affecting implementation of corporate strategies in the electricity sector in Kenya (a case of Kenya Electricity Generating Company Limited)

26. Njoroge, E. (2018). Effects of strategic planning on organizational performance: A case of event planning firms in Nairobi $C B D$ (Doctoral dissertation, United States International UniversityAfrica).

27. Okoth, J. O. (2016). Effect of Stakeholder's Involvement In Strategy Formulation And Implementation On Organizational Performance, Among Tea Warehousing Companies in Mombasa County, Kenya (Doctoral dissertation, University Of Nairobi).

28. Oliver, C. (1991). Strategic responses to institutional processes. Academic Management Review, 1(6), 145-179

29. Otoo, F. (2016). Effect of communication on employee performance at Ghana Revenue Authority, Kumasi (Doctoral dissertation).

30. Owolabi, S. (2015). The effects of strategic planning on corporate performance in univerity education. Kuwait Chapter of Arabian Journal of Business \& Management Review, 2(4), 116-119

31. Rajagopalan, N., Rasheed, A. M., \& Datta, D. K. (2019). Strategic decision processes: Critical review and future directions. Journal of Management, 19(2), 349-384

32. Rintari, H., \& Moronge, M. (2012). Role of Strategic Planning Practices on the Performance of Public Institutions in Kenya. International Journal of Science and Research, 3(358), 919924. 
33. Steiner, G. A. (2014). Strategic Planning, The Free Press, New York, NY.

34. Tang, Z., Powell, B., Marino, L., Tang, J., \& Dickson, P. (2015). The impact of organizational goal setting on the industrial munificencegoal attainment relationship. International Journal of Business and Management, 3(3), 107-124.

35. Teece, D. J., Pisano, G., \& Shuen, A. (1997). Dynamic capabilities and strategic management. Strategic management journal, 18(7), 509-533.

36. Teo, T. C., \& Low, K. C. P. (2016). The impact of goal setting on employee effectiveness to improve organization effectiveness: Empirical study of a high-tech company in Singapore. Journal of Business \& Economic Policy, 3(1), 1-16.

37. Umar, A. A., Muhammad, N., \& Hassan, I. (2020). Strategic Planning Process and Organizational Performance in Nigerian Public Sector: A Review of Literature, (Doctoral Dissertation, University of Nigeria)

38. Vudzijena, L. S. (2017). An analysis of the impact of environmental scanning on the performance of Small and Medium Retail Enterprises in Harare. (Doctoral dissertation, University of Zimbabwe)

39. Wakahia, T. N. (2017). Strategic planning practices and performance of Kenya Women holding Limited (Doctoral dissertation, University of Nairobi).

40. Weick, K. E., \& Quinn, R. E. (2016). Organizational change and development. Annual Review of Psychology, 50(4), 361-386

41. West, J. J., \& Olsen, M. D. (2016). Environmental scanning and its effect upon firm performance: An exploratory study of the foodservice industry. Hospitality Education and Research Journal, 12(2), 127-136 